\title{
DETERMINING THE SEVERITY OF SKIN INJURIES OF RED MULLET, MULLUS BARBATUS (ACTINOPTERYGII: PERCIFORMES: MULLIDAE), INFLICTED DURING ESCAPE FROM TRAWL CODEND
}

\author{
Faik Ozan DÜZBASTILAR ${ }^{1 *}$, Tarkan LALELI ${ }^{2}$, Aytaç ÖZGÜL ${ }^{3}$, and Gülnur METIN ${ }^{1}$ \\ ${ }^{1}$ Faculty of Fisheries, Ege University, İmir, Turkey \\ ${ }^{2}$ Graduate School of Natural and Applied Sciences, Ege University, İzmir, Turkey \\ ${ }^{3}$ Centre of Underwater Research and Application, Ege University, İzmir, Turkey
}

\begin{abstract}
Düzbastılar F.O., Laleli T., Özgül A., Metin G. 2015. Determining the severity of skin injuries of red mullet, Mullus barbatus (Actinopterygii: Perciformes: Mullidae), inflicted during escape from trawl codend. Acta Ichthyol. Piscat. 45 (1): 75-83.
\end{abstract}

Background. The authors suggest that skin injury, particularly scale loss, during the capture may be one reason of the escape mortality. However, skin and fin damages are not responsible for all of the observed mortalities occurring during the fish passage through the mesh of the trawl codend. Nevertheless, physical damages may expose escapees to secondary infections from bacteria and fungi. This study investigated the types and occurrence of deformation for red mullet escapees to better understand the cause of their death. Improving the survival rate by using alternative gear modifications require detailed information on assessments of escape mortality including trawl gear-induced injuries. Therefore we aimed to determine the damages of body parts among the escaped red mullet from trawl codends.

Materials and methods. Injuries and mortalities sustained by red mullet, Mullus barbatus Linnaeus, 1758, escaping from three different trawl codends were investigated in the Aegean Sea within 10-18 February 2012. The fish were held captive in fish cages and their behaviour was observed by divers three times per day for a period of 9 days. During the observation, dead fish were removed and immediately transferred to the laboratory for measurement and post-mortem examination.

Results. The rates of escape mortality of red mullet penetrating through $40 \mathrm{~mm}$ square mesh codend, $44 \mathrm{~mm}$ diamond mesh codend, and $50 \mathrm{~mm}$ diamond mesh codend were $26.3 \%, 46.3 \%$, and $27.4 \%$, respectively. In total, 323 red mullet died after escaping from codends. Two of these could not be examined because of post-mortem decomposition and 21 others were defined as undamaged. Scale loss was the most common injury (300 fish, $93.5 \%$ ) in red mullet individuals that died due to post escape mortality. The second most common injury was tissue loss $(34.6 \%)$ followed by skin loss $(19.9 \%)$. The majority of scale damage cases was around the abdomen and on either side of the caudal peduncle. In general, the frequency of the scale loss increased towards the tail. The frequency of different fin injuries of escaped fish were: $58.6 \%$ (torn), $44.5 \%$ (broken), and $6.2 \%$ (loss), respectively.

Conclusion. Red mullet escape mortality was highly correlated to fish length $(P<0.001)$, however, we identified no clear relation between fish size and scale loss.

Keywords: fish, damage, scale loss, escape mortality, Aegean Sea, codend

\section{INTRODUCTION}

Bottom trawling involves towing a trawl along the sea floor and is a principal contributor to discard and escape mortality during commercial fishing. Of these, the escape mortality was defined by ICES (Anonymous 2004) as the mortality of organisms that actively escape from a gear prior to the catch being landed by the fishing operation. Escape mortality occurs as a result of interaction between the fish and the trawl during the capture process and it includes physical injury, exhaustion, and stress (Breen 2004). Target and non-target species may be injured while escaping from the trawl gear usually by passing through the mesh of the codend (Wileman et al. 1996). Gilman et al. (2013) defined the escape mortality as pre-catch losses that occur when organisms escape from the fishing gear alive but die later. The escape mortality is a component of unaccounted fishing mortality (Suuronen 2005). Fishing experiments have been performed to estimate the rate of delayed

\footnotetext{
* Correspondence: Assoc. Prof. Dr. F. Ozan Düzbastılar, Ege Universitesi, Su Ürünleri Fakültesi, 35100 Bornova İzmir, Turkey, phone: +90 533 5710906, fax: +90 232 7520015, e-mail: (FOD) f.ozan.duzbastilar@ege.edu.tr,duzbastilar@gmail.com, (TL) tarkan.laleli@gmail.com, (AÖ) aytac.ozgul@ege.edu.tr, (GM) gulnur.metin@ege.edu.tr.
} 
mortality by monitoring the captured fishes in cages (Anonymous 2004), tagging and recapturing fish (Anonymous 2004), or under controlled environments in experimental tanks (Broadhurst et al. 1997, Davis and Ottmar 2006, Olsen et al. 2012).

Numerous survival studies have been carried out over the past two decades on the northwest coast of Scotland, in the North Sea, the northern Baltic Sea, and the Barents Sea (Main and Sangster 1990, Sangster et al. 1996, Suuronen et al. 1996a, Broadhurst et al. 2006, Ingólfsson et al. 2007). However, there have hitherto been only a few studies (Metin et al. 2004, Düzbastılar et al. 2010a, 2010b, 2010c) attempting to estimate the mortality of fish escaping from the trawl codend in the Mediterranean. Thus, there is little available information on how escape mortality during commercial bottom trawling is affected by factors such as: codend mesh size and shape, fish size, species-specific variation, and the type of skin injury (Suuronen 2005). However, a number of studies have addressed escape mortality for some demersal fishes from the Aegean Sea, such as: red mullet, Mullus barbatus Linnaeus, 1758; annular seabream, Diplodus annularis (Linnaeus, 1758); blotched picarel, Spicara maena (Linnaeus, 1758); brown comber, Serranus hepatus (Linnaeus, 1758); and black goby, Gobius niger Linnaeus, 1758; and the causative role of several factors such as the mesh size and shape, fish size, species-specific variation, and water temperature (Metin et al. 2004, Düzbastılar 2010a, 2010b, 2010c).

Physical injuries such as skin and scale damage can lead to stress which is known to adversely affect the fish immune system and thus contribute to a disease and death (Rottmann et al. 1992). Physical injuries might also affect fish vital functions, resulting in mortality due to elimination or limitation of the mechanical protection, dehydration, limitation of the physical endurance, and elimination or limitation of pathogenic protection (Suuronen 2005, Breen 2004, Ingolfsson et al. 2002, Davis and Ottmar 2006, Olsen et al. 2012). Deformation of scales and skin, which are protective physical barriers, can increase the susceptibility to infection (Rottmann et al. 1992). Metin et al. (2004) and Düzbastılar et al. (2010b) observed scale loss and sores on red mullet individuals held in cages after escape. However, an assessment of injuries to red mullet individuals escaping from trawl codends has not been made in the Mediterranean Sea.

The aim of the presently reported study was to investigate the damages occurring in red mullet, Mullus barbatus, escaping through trawl codends. The most prevalent damages that may contribute to fish mortality are: scale loss, skin injuries, and fin damages. In addition, the behaviour of the injured fish held in cages was observed by divers and recorded using underwater camera systems.

\section{MATERIAL AND METHODS}

Trawl trials were performed on board the R/V Egesüf (27 m length, $405 \mathrm{~kW}$ engine) off the southern coast of Yassica Island in İzmir Bay (Fig. 1) between 10 and 18
February 2012. A diving logistic boat (Egederin, $10 \mathrm{~m}$ length, $121 \mathrm{~kW}$ ) was used for all diving operations. A total of nine, 15-min tows were carried out within 10-11 February 2012. The fishing gear was a customdesigned bottom trawl with 800 meshes around the codend entrance perimeter. Three different polyethylene (PE) codends were used: $40 \mathrm{~mm}$ square mesh (40S) $(75$ bars around the perimeter and $5 \mathrm{~m}$ in length); $44 \mathrm{~mm}$ diamond mesh (40D) (150 meshes around the perimeter and $5 \mathrm{~m}$ in length), and $50 \mathrm{~mm}$ diamond mesh (50D) (132 meshes around the perimeter and $5 \mathrm{~m}$ in length). Codend covers were designed to retain escaping fishes. They were made of polyamide (PA) diamond mesh netting to minimize abrasive injury to the captive fish ( $24 \mathrm{~mm}$ mesh size, $7.5 \mathrm{~m}$ in length and 450 meshes around the perimeter at the maximum diameter). The covers, used for housing the sampled fish, were supported by two high-density polyethylene (HDPE) hoops of $0.8 \mathrm{~m}$ in radius. All cages were rigged out with $1 \mathrm{~m}$ long zipper to permit collection of the dead fish and feeding the survivors. Using the experimental protocol for collecting and monitoring fish escaping from codends described in Metin et al. (2004), the covers were immediately detached from the codends and horizontally deployed to the sea bottom by divers. To prevent anoxia by providing the maximum cage volume of $7.5 \mathrm{~m}^{3}$, the cages were stretched from one end to the other using ropes and wooden rods. Total mortality was calculated as the percentages of red mullet found dead in each cage.

Behaviour of captive fish in the cages. The behaviour of the caged fish was observed by divers three times a day over a 9-day period. The observations were recorded by an underwater camera in the form of video clips and photographs. The camera system was mounted permanently to avoid scaring he fish in the seabed cages (Fig. 2). The video and illumination system NEMOSUB NVS-102-16

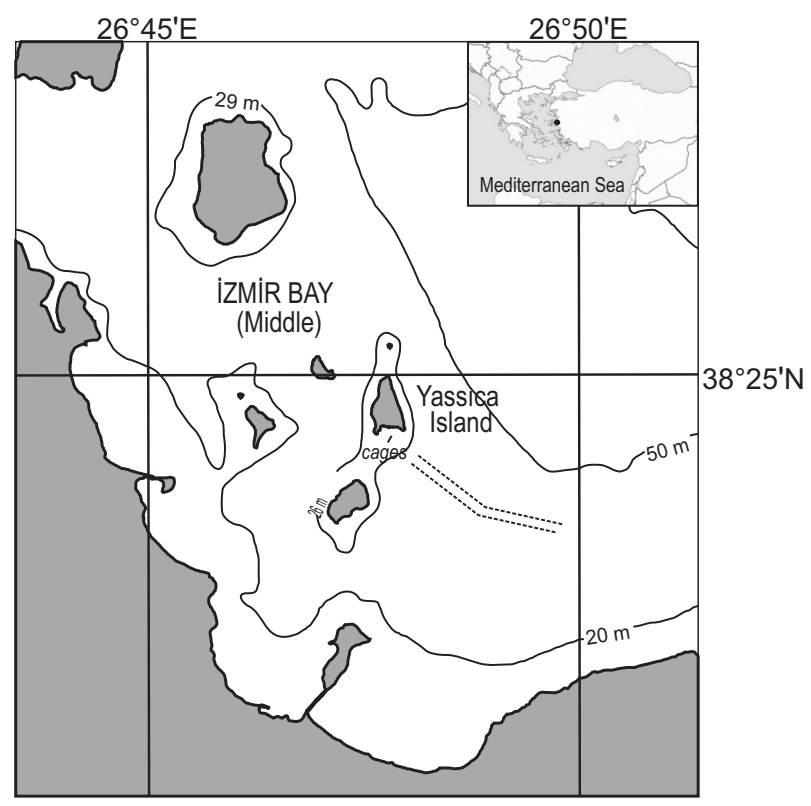

Fig. 1. Study area: indicating the site of observations cages and the trawling tracks for the experiments 
was fixed to the inner surface of the observation cage by scuba divers. The system consisted of $100 \mathrm{~m}$ polyethylene cable, a fixed focused camera, 560 lumen light system, $40.64 \mathrm{~cm}$ colour LED monitor, and DVR and back-up flash drive. The recordings were downloaded from the hard disk, converted to an avi format and viewed using the GOM Media Player*. In addition divers used a digital handheld video camera (Sony PC350E, Sea\&Sea housing) and underwater camera (Nikon D200, Sea\&Sea housing) to record behaviour of the fish in the cages.

Post-mortem examinations. During the study period cages were observed by divers three times a day. The fish were fed and the dead or moribund individuals were removed from the cages. Frequent observations and removal of dead fish was needed to minimize predation and scavenging of carcasses, which could lead to major organ loss (e.g., caudal fin and head), which could bias the data on injuries resulting in mortality. During the monitoring period, dead fish were removed by divers using knotless netting bags to prevent further damage. Specimens were placed in a transportation cold box and transferred to the laboratory for measurement and postmortem examination. The transportation time was shorter

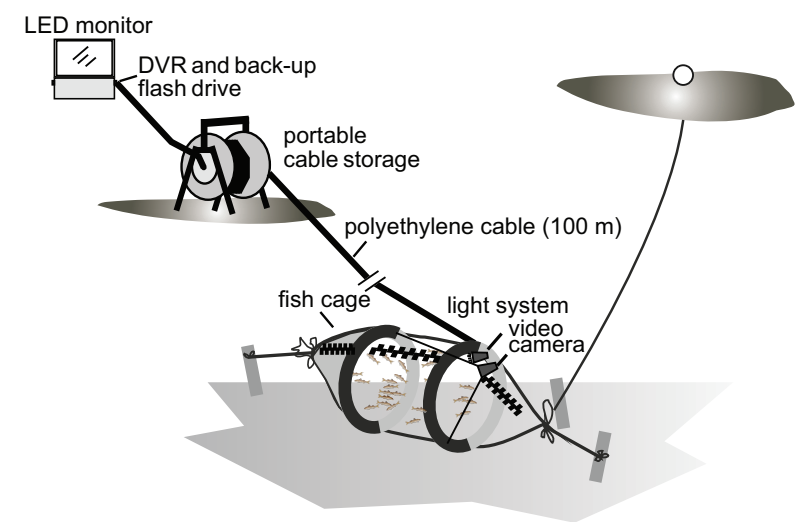

Fig. 2. Configuration of underwater camera and cage systems
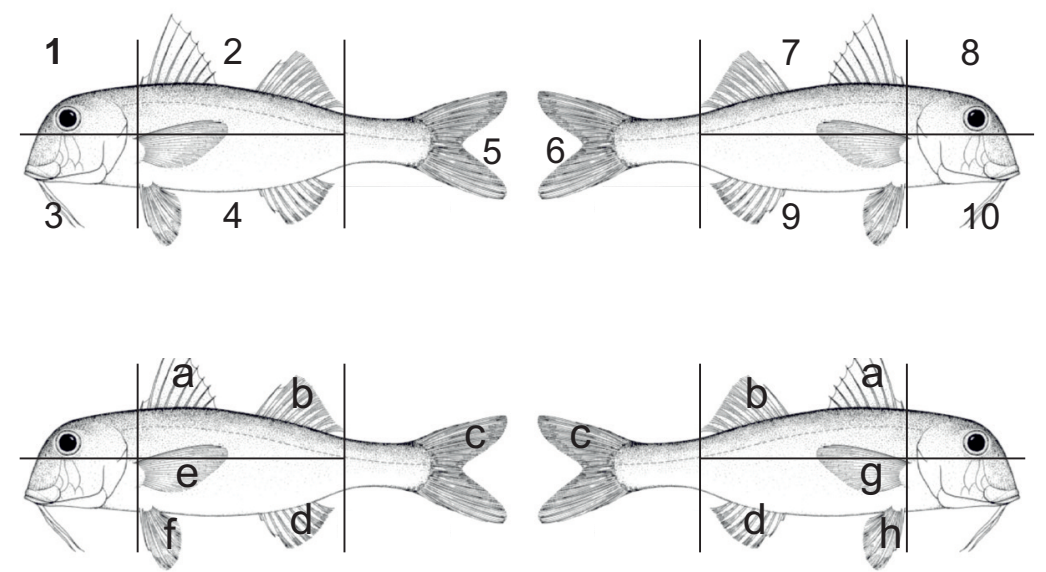

than $1 \mathrm{~h}$. At the end of the observation period, the cages were lifted up, and survivors were counted, and their lengths were measured. The 9 days monitoring period was chosen because the majority of the deaths have been shown to occur within the first 48 to $72 \mathrm{~h}$ after capture (Metin et al. 2004, Düzbastılar 2010b).

A photograph was taken of both flanks of each specimen using a digital camera (Nikon D200) and examined to determine major injuries. After the visual examination, all fish were weighed and measured. Total and standard lengths were measured in $0.5 \mathrm{~cm}$ increments. Post-mortem examinations focused on recording injuries because the tissues of deceased fish would rapidly deteriorate after death. Nevertheless, an external visual examination (scale, skin, and tissue loss) was carried out for each fish. Both flanks of every fish were visually subdivided into five sections and scale, skin, and tissue losses were determined as in the methodology used by Main and Sangster (1990) (Fig. 3). Red mullet individuals that had suffered skin injuries or fin damage were counted thus accounting for cases when unique or multiple injuries occurred in different body parts (thus an inspected individual might have simultaneously suffered from scale, skin and tissue loss or fin injuries). The degree of external damage within each body region was classified either as loss of scales only, loss of skin (including scales), or loss of tissue. If only scale loss had occurred the loss sections were identified among the ten defined sections. Skin deformation was classified as loss of skin (including scales). Tissue loss was determined including scale and skin deformations. Deterioration and physical impacts on fin rays (caudal, pectoral, etc.) were classified into three groups:

- Torn fin;

- Broken fin ray; and

- Fin loss (partial or total).

The general linear model (GLM) repeated measures test was used to determine differences in the number of skin injuries and fin deformations with each length category. The statistical analyses were performed using SPSS

Fig. 3. Diagram used to determine visually the scale, skin and tissue losses (1-10) and fin deformations (a-h) on each individual of red mullet, Mullus barbatus 
(version 15.0). Mortality data were analysed using a GLM selected for binomial error distribution and logit-link function. GLM statistical analyses for escape mortality were performed using the R statistical program (R Development Core Team 2007).

\section{RESULTS}

Fish cages and behaviour of captive fish. A total of 25 species and 2905 individuals escaped from the nine test codends. These escapees were retained by the cover nets and transferred to the fish cages for observation. The most abundant species in terms of numbers of individuals (in the brackets) were: red mullet, Mullus barbatus (930); common pandora, Pagellus erythrinus (Linnaeus, 1758) (614); blotched picarel, Spicara maena (459); solenette, Buglossidium luteum (Risso, 1810) (380); black goby, Gobius niger (125); and brown comber, Serranus hepatus (61).

On the day of capture, to prevent escapement of fish during the observation period, divers checked all parts of the cages for torn meshes and ensured that the zippers and knots were secure. The divers recorded the behaviour of the captive fish over the following 8 days. It was noted that the fish reacted to the divers; when the cage zipper was opened to collect red mullet mortalities, survivors would avoid the divers and escape to safe parts of the cage. It was observed that red mullet swam in groups. One group of red mullet was seen to descend into the cage bottom. The red mullet also exhibited food-searching behaviour, tracing their barbells across the sea bottom before ascended towards the upper parts of the cage. Although the red mullet initially showed no interest in feeding, after a few days they swam upward from the sea bottom and fed on detritus on the upper and lateral meshes of the cages.

Injured red mullet, Mullus barbatus, became less active and disassociated themselves from the fish shoal. In most cases they continued to swim in a head-up verti- cal position but had difficulty in swimming and in maintaining their position. Considerable whitening around the head region was often noted due to friction between the skin and the netting material. After losing their ability to swim, injured individuals were observed on the bottom of the cage. Although the majority mortalities were found on the bottom of the fish cage, a few individuals died and remained at the upper part of the cage.

Post-mortem assessment of injuries was not always possible because of predation and deterioration resulting in the loss of body parts. Therefore, some moribund fish were collected by divers before death to prevent further scavenging.

Post-escape mortality of red mullet. In total, 930 red mullet, Mullus barbatus, ranging from 7.0 to $15.4 \mathrm{~cm}$ in length were captured during the escapement experiments. The majority of the observed deaths occurred within the first 2 days following escape, resulting in mortality of $62 \%, 67 \%$, and $53 \%$ for the $40 \mathrm{~S}, 44 \mathrm{D}$, and $50 \mathrm{D}$ test cages, respectively. At the end of the monitoring period, for the 40S test cages $63(39.1 \%), 27(21.3 \%)$, and $7(18.4 \%)$ dead fish were found in cages 1,2 , and 3 respectively, equating to a mean mortality of $26.3 \%$ (Table 1 ). For the 44D test cages $100(48.8 \%), 14(44.2 \%)$, and $18(45 \%)$ dead fish were found in cages 1,2 , and 3, respectively, equating to a mean mortality of $26.3 \%$. For the $50 \mathrm{D}$ test cages $29(22.7 \%), 52(35.9 \%)$, and $13(23.6 \%)$ dead fish were found in cages 1,2 , and 3 , respectively, equating to a mean mortality of $34.7 \%$.

Injuries of red mullet-post-mortem examination. A total of 321 deceased fish were inspected to determine the extent of their injuries (Fig. 4). No inspection was carried out among the survivors. Although the frequency of diver inspections was sufficient for winter conditions, varying states of decomposition and predation were observed among the examined fish because of the rela-

Data from the survival experiment of red mullet, Mullus barbatus, subjected to injures

Table 1 by the trawl codend; February 2012; the Aegean Sea

\begin{tabular}{|c|c|c|c|c|c|c|c|c|}
\hline \multirow{2}{*}{ Mesh } & \multirow{2}{*}{ Cage No. } & \multirow{2}{*}{$N_{\mathrm{M}}$} & \multirow{2}{*}{$N_{\mathrm{RM}}$} & \multirow{2}{*}{$N_{\mathrm{AF}}$} & \multicolumn{2}{|c|}{ Length $[\mathrm{cm}]$} & \multirow{2}{*}{ Mortality [\%] } & \multirow{2}{*}{ Depth [m] } \\
\hline & & & & & Range & Mean \pm SD & & \\
\hline \multirow{3}{*}{$40 \mathrm{~S}$} & 1 & 63 & 161 & 503 & $8.9-13.4$ & $11.1 \pm 1.1$ & 39.1 & 4.9 \\
\hline & 2 & 27 & 127 & 385 & $8.3-12.5$ & $10.4 \pm 1.3$ & 21.3 & 5.0 \\
\hline & 3 & 7 & 38 & 158 & $12.6-12.8$ & $12.7 \pm 0.1$ & 18.4 & 4.9 \\
\hline \multirow{3}{*}{$44 \mathrm{D}$} & 1 & 100 & 205 & 500 & $10.4-13.1$ & $11.4 \pm 1.2$ & 48.8 & 5.2 \\
\hline & 2 & 14 & 31 & 167 & $7.0-10.9$ & $9.6 \pm 0.9$ & 45.2 & 4.5 \\
\hline & 3 & 18 & 40 & 250 & $12.0-12.9$ & $12.3 \pm 1.3$ & 45.0 & 5.1 \\
\hline \multirow{3}{*}{$50 \mathrm{D}$} & 1 & 29 & 128 & 385 & $8.5-11.6$ & $10.0 \pm 1.0$ & 22.7 & 5.1 \\
\hline & 2 & 52 & 145 & 309 & $9.1-13.2$ & $10.9 \pm 1.1$ & 35.9 & 5.1 \\
\hline & 3 & 13 & 55 & 248 & $9.3-12.0$ & $10.8 \pm 0.9$ & 23.6 & 5.2 \\
\hline
\end{tabular}

Mesh = mesh code, $N_{\mathrm{M}}=$ number of mortalities, $N_{\mathrm{RM}}=$ number of red mullet, $N_{\mathrm{AF}}=$ number of all fish, Mortality $=$ mortality of red mullet, Depth = anchoring depth of the cages; $40 \mathrm{~S}=40 \mathrm{~mm}$ square mesh, $44 \mathrm{D}=44$ diamond mesh, 50D $=50$ diamond mesh . 

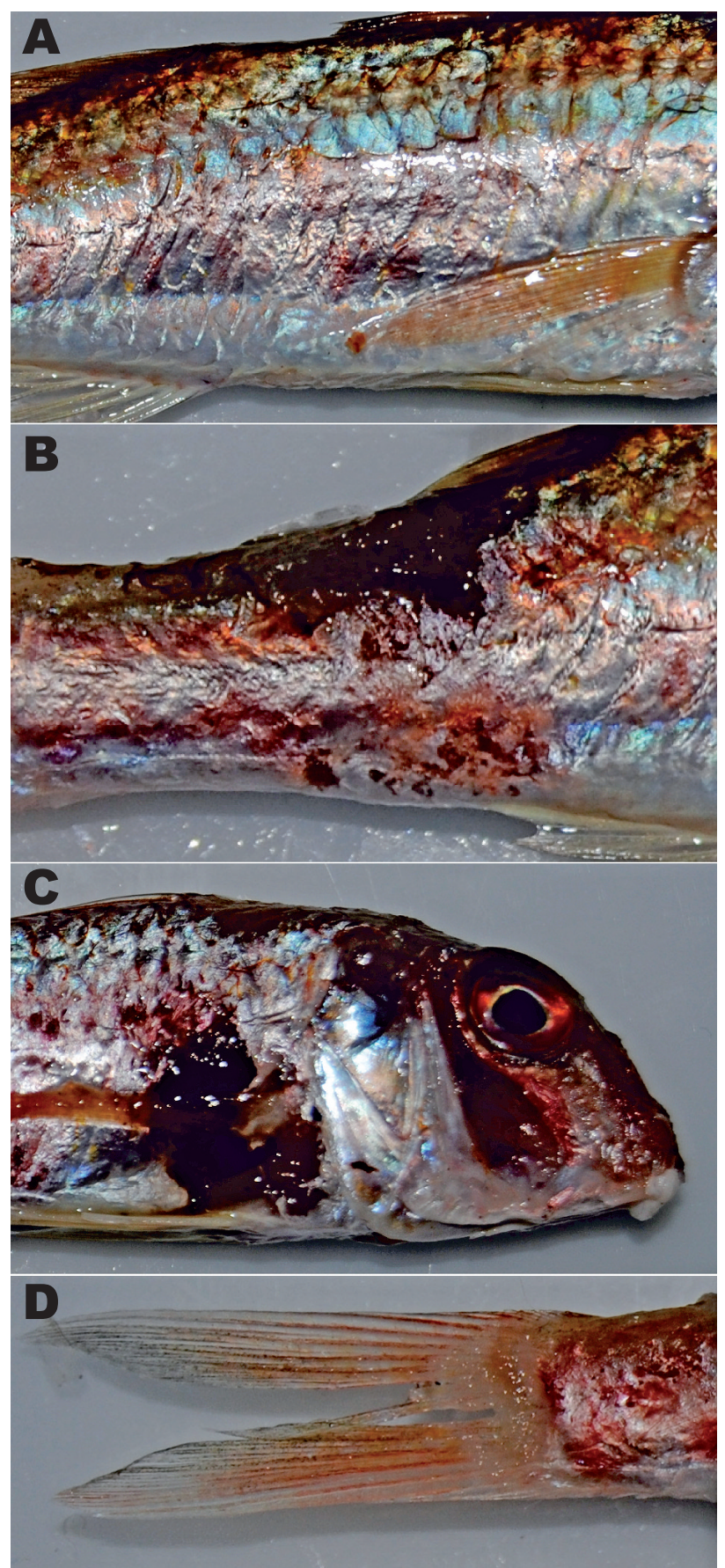

Fig. 4. Injuries of specimens of red mullet, Mullus barbatus: A, scale loss; B, skin loss; $\mathbf{C}$, tissue loss (pectoral fin and operculum); $\mathbf{D}$, torn caudal fin tively long time $(\sim 13 \mathrm{~h})$ between morning inspection and the last inspection of the preceding day. The extent of the injuries sustained whilst escaping could not be determined in two of the specimens because of extensive post-mortem decomposition and scavenging (Fig. 5).

Each flank of the fish was photographed for scoring of scale, skin and tissue loss. Next, fins (first dorsal and second dorsal, pelvic, pectoral, anal, and caudal fins) were inspected for evidence of physical injury and damage. Finally, detailed macroscopic and visual examination of internal tissues and organs was undertaken.

Taken together, our data indicate that $93.5 \%$ (300/321) of mortalities can be attributed to some form of injury (e.g., scale loss, skin damage, or fin deformations) (Fig. 6). The remaining 21 deceased fish had no deformations, while two fish were excluded because of advanced decomposition. Almost all of the red mullet individuals had scale damage. Scale loss $(93.5 \%)$ was the most common injury in the escaped red mullet, followed by tissue loss (34.6\%) and skin loss (19.9\%) (Fig. 6). In total, 175 fish suffered from skin injuries. Fin injuries were identified in 58.6 (torn), 44.5 (broken), and 6.2\% (loss) of the escaped red mullet (Fig. 6).

The occurrence of scale loss differed significantly among the body sections $(P<0.05)$. By visual examination, the most damaged scale parts of the red mullet were the caudal (sections 5 and 6) and belly regions (sections 4 and 9) (Fig. 7). On the left flank, there was a significant $(P<0.05)$ difference among all body sections, except for sections 4 and 5 . For the right side of the fish body, there were significant differences among all body sections $(P<0.05)$. When comparing the right and left sides of the fish, we found no significant difference between sections 5 and 6, which represents the caudal peduncle.

Approximately $20 \%$ of the inspected individuals had only skin injury. Although skin injuries were identified over all areas of the fish bodies, the upper part of the head (section 1) was the most deformed (mean rate, $58.5 \pm$ $4.1 \%$ ) (Fig. 7). On the left flank there was no significant difference between sections 1 to 4 and 2 to $3(P>0.05)$. For the right flank there was a significant difference between sections 7 to 10 and 9 to $10(P<0.05)$. For each flank of the fish body, we identified no significant differences between sections 4 to 9 and 5 to $6(P>0.05)$. In addition, after the cage installation and during underwater observation, skin injuries were initially observed on the

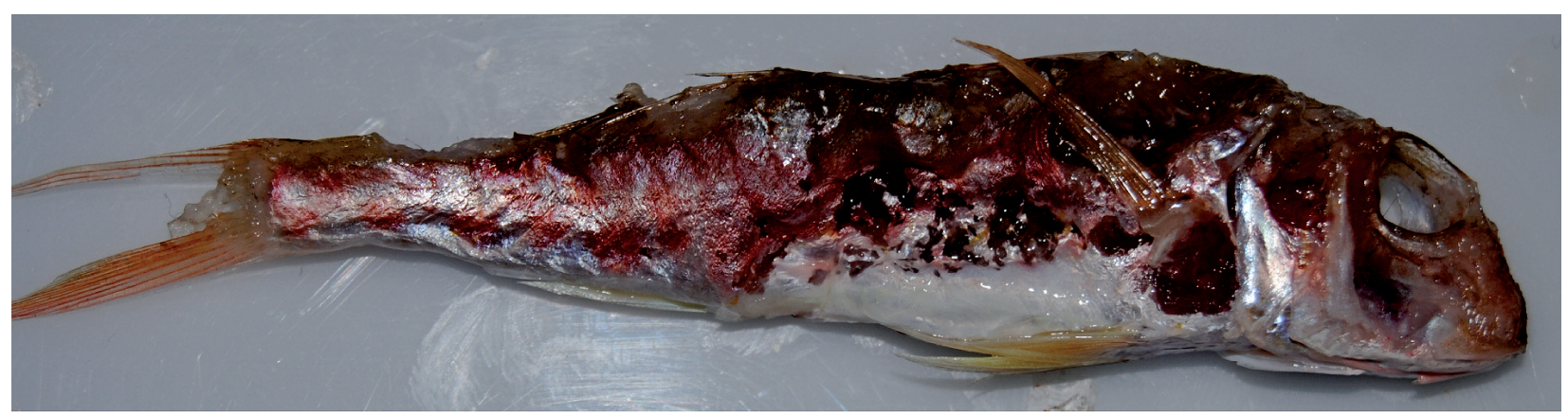

Fig. 5. Decomposition of a specimen of red mullet, Mullus barbatus 
abdomens and around the fish heads, particularly on the snout. There was a minor difference between the left and right sides of the red mullets for injury rate, with mean rates of $57.8 \%$ and $59.2 \%$ for the left and right side, respectively. The overall rate of skin injuries was $54.5 \%$ (skin loss plus tissue loss).

More than a third of red mullets suffered tissue damage $(54.5 \%)$. A major proportion of the observed tissue loss (including hard and soft tissues) occurred on the top of the head (sections 1 and 8) (mean, 73.6 \pm 18.4 ) (Figs. 6 and 7). Tissue loss was lowest in section 10 and this was statistically different from the other sections $(P<0.05)$.

Three marked damages were seen on the fins of fish examined from the survival experiment (Fig. 8). In total, $188 / 321$ fish suffered fin damages, including torn, broken and partially or totally loss fins. The caudal fin was the most injured for all damage types: 188, 143, and 20 with torn, broken, and lost caudal fins respectively. The second dorsal (184), pectoral (157 and 154), and anal (155) fins were the next most commonly damaged. The dorsal and caudal fins were significantly more damaged than the other fins $(P<0.05)$. A large number of broken fin rays occurred in the second dorsal (113) and pectoral (107 and 100) fins. All categories were significantly different from each other $(P<0.05)$. The caudal fins of fish that were partially $(>50 \%)$ or totally lost had the highest proportion and severe lost followed by pectoral fin (g: 15) and pelvic fin (h: 14) $(P<0.05)$.

\section{DISCUSSION}

After capture, individuals of red mullet, Mullus barbatus, were held in captivity for 9 days. This could lead to captivity stress brought on by the high fish population within the cage, competition for food, prey-predator effects, the artificial environment, and limited movement (Breen 2004). On the other hand, the injured fish inside the fish cages were also protected from outside predators. Divers made observations of the behaviour of captive fish three times a day for 9 days. A fixed underwater camera system was used to eliminate potential negative or positive reactions by the fish towards the divers. We observed a difference among species in terms of movement and distribution within the cages. Breen (2004) reported that haddock were more likely to be seen at the bottom of the cages, whereas whiting preferred the upper cage section. Düzbast1lar (2010a) observed that species such as annular seabream, two-banded seabream, Diplodus vulgaris (Geoffroy Saint-Hilaire, 1817), common pandora, and brown comber were seen to quickly adapt to their new environment, however damaged fish as blotched picarel, red mullet, and black goby attempted to disassociate themselves from the main shoal.

In summertime experiments, Metin et al. (2004) and Düzbast1lar (2010a) reported mortality rates of $6.8 \%$ and $18.8 \%$ for red mullet escaping from a $40 \mathrm{~mm}$ diamond mesh codend. In our study, the mortality of red mullet escaping from the 44D mesh codend was greater $(46.3 \%)$ than those reported in the above cited articles. However, the 40S and 50D mesh codends had lower mortality rates (26.3\% and $27.3 \%$, respectively). Düzbast1lar (2010a) reported a low mortality rate $(<5 \%)$ for red mullet escaping from $40 \mathrm{~S}$ mesh codend. Variability in the environmental conditions or the state of the fished stock could

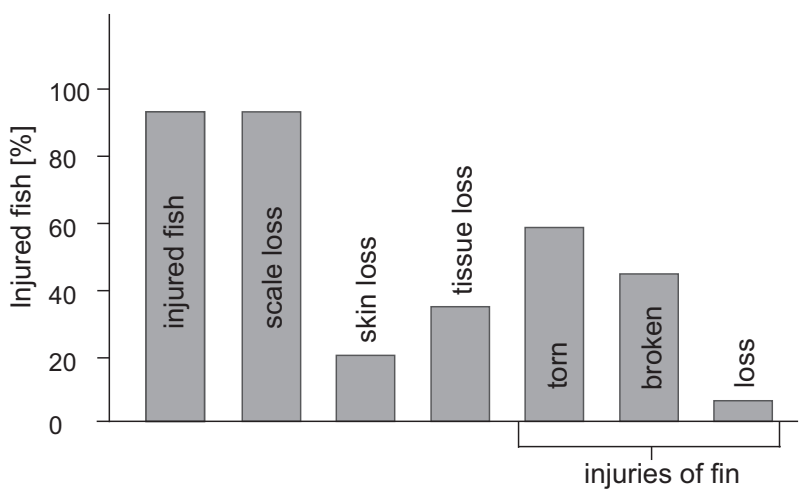

Fig. 6. Scale, skin and tissue loss of left and right sides of red mullet, Mullus barbatus subdivided into ten zones

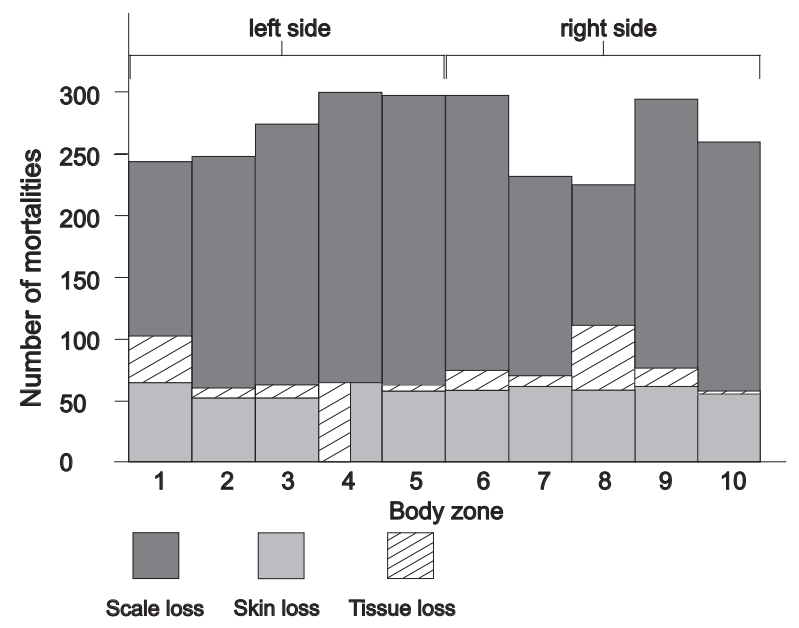

Fig. 7. The rate of injuries in mortalities of red mullet, Mullus barbatus, shown by post-mortem inspection

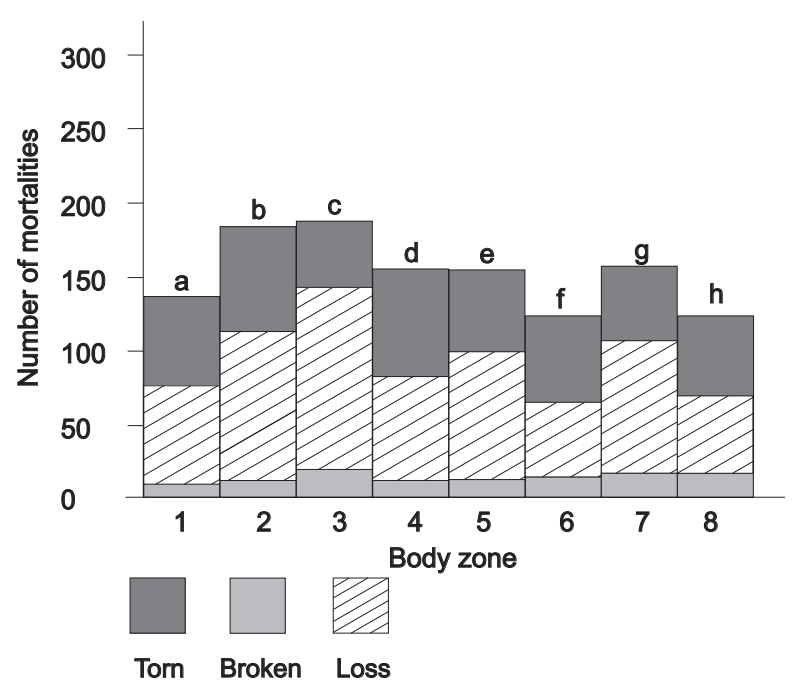

Fig. 8. Injuries to fins in both sides of red mullet, Mullus barbatus: $\mathrm{a}=$ first dorsal fin, $\mathrm{b}=$ second dorsal fin, $\mathrm{c}=$ caudal fin, $\mathrm{d}=$ anal fin, $\mathrm{e}-\mathrm{g}=$ pectoral fins, $\mathrm{f}-\mathrm{h}=$ pelvic fins 
lead to variations in the escape mortality for experiments preformed in different years. Survival studies have shown that there was no significant relation between codend catch sizes and escape mortality (Suuronen et al. 2005). Nevertheless, some studies have demonstrated that escape mortality generally increases with the fish population in the cages (Breen 2004). In our study, the effect of fish population was not clear for the test cages. Although previous experiments have been conducted towards the end of the summer (with water temperatures of $21-25^{\circ} \mathrm{C}$ ), the water temperature was $\sim 13^{\circ} \mathrm{C}$ in our study. Low water temperature may affect the fish behaviour, such as decreasing swimming speed and endurance ( $\mathrm{He}$ and Wardle, 1988) and also the escapement ability of fish from the codend. Therefore, it is likely that seasonal factors, such as water temperature (that was $8-10^{\circ} \mathrm{C}$ higher in the previous experiments), fish condition, and size structure of the captured population, have been responsible for the relatively large mortality rate reported in this study. The multi-species nature of the catch ( 25 species) as well as the fish size within the fished population was problematic and complicated the sampling and observing processes of this study.

Scale and skin damages of the fish play an important role in fish mortality (Broadhurst et al. 1997, Ingolfsson et al. 2002, Davis and Ottmar 2006). Mortality caused by secondary infections such as various skin infections, lesions, and lack of fins was observed for many fish species (Main and Sangster 1990, Soldal et al. 1993, Sangster et al. 1996, Ingolfsson et al. 2002, Breen 2004). The assessment of the mortality induced by secondary infections needs long-term and more specific studies (e.g., involving telemetry, tagging, etc.). On the other hand some principle symptoms can be determined by helping with the observation period and post-mortem experiments. The findings of our short-term study (including underwater observations and post-mortem examinations) demonstrate that most $(93.5 \%)$ of the escapees experienced scale loss, which ultimately resulted in mortality. Only a small number of the fish (21/321) that suffered from escape mortality had no visible injuries.

During capture many vital functions (e.g., mechanical protection, resistance to bacterial infection, communication and swimming ability) can be affected by external factors, such as abrasive netting materials, larger fish with sharp body parts in the codend, and debris (Main and Sangster 1990, Ingólfsson et al. 2002, Suuronen 2005). Suuronen et al. (1996b) proposed that skin injuries and exhaustion are mainly responsible for the high escape mortality rates and that survival probability does not depend on the codend mesh size. In our study, the mortality rate of red mullet escaping from the 44D test cages $(46.3 \%)$ was significantly higher than that of the $40 \mathrm{~S}$ $(26.3 \%)$ and 50D (27.4\%) test cages. Although we did detect a difference among the mortality rates of the test cages this was not related to mesh size or shape.

Previous survival studies carried out at the same site (Metin et al. 2004, Düzbast1lar et al. 2010a, 2010b, 2010c) did not investigate the role of scale and skin damages on fish mortality. Metin et al. (2004) performed only a visual post-mortem examination for red mullet within the first $24 \mathrm{~h}$ following capture. The flank was divided into $6 \mathrm{sec}-$ tions for analysis of scale loss and skin injuries, with the majority of red mullet individuals $(30 \%-50 \%)$ having both scale loss and skin injuries in these body sections, including the upper part of the fish head, around the dorsal fins and the abdomen.

Some fish, particularly larger fish, showed high resistance to fishing gear damage (Soldal et al. 1991, 1993, Sangster et al. 1996, Ingolfsson et al. 2002). Soldal et al. (1991) found negligible scale loss for cod, Gadus morhua Linnaeus, 1758, larger than $30 \mathrm{~cm}$ and for saithe, Pollachius virens (Linnaeus, 1758); larger than $40 \mathrm{~cm}$ occurring at a ratio of $1 \%-2 \%$. Investigations on skin injury and tissue losses have shown a relation between the injury and fish length. There is broad consensus that smaller fish with low physical endurance and swimming capabilities are badly affected during trawling (Soldal et al. 1991, Breen 2004). Although some authors have observed scale loss to be dependent on fish size (Soldal et al. 1991), other studies have shown that injuries were unrelated to fish length (Ingólfsson 2006). Although our study was primarily focused on investigating the types of damages occurring in red mullet escapees, it was clear from our data that fish length was related to escape mortality. Ingolfsson et al. (2002) also determined that saithe suffered small scale losses $\left(<1 \mathrm{~cm}^{2}\right)$; however, this did not lead to mortality. Ingolfsson et al. (2002) recorded the scale injuries occurring on the left and right flanks of 185 haddock. Of these, scale loss was found in nearly $80 \%$ of
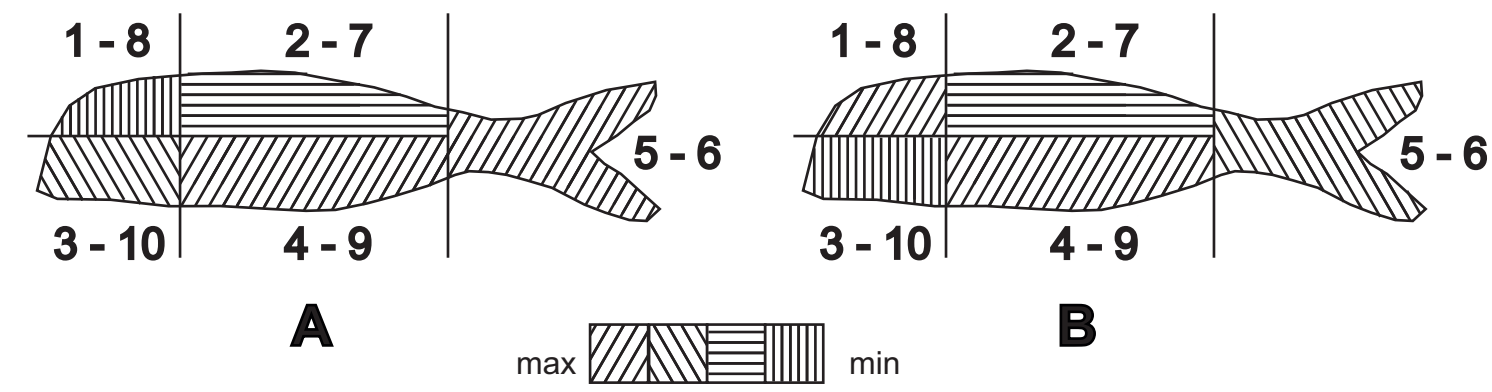

B

Fig. 9. Diagram of both sides of red mullet, Mullus barbatus, showing intensity of scale (A) and skin (B) loss 
haddock escaping from codend meshes. Soldal et al. (1991) observed a high (almost 100\%) rate of scale loss for haddock smaller than $25 \mathrm{~cm}$. Nevertheless, they argued that scale loss might be regarded as a descriptive variable of mortality for haddock. In our study, scale losses were more frequent than skin and tissue losses. Red mullet have large scales that are easily detached (Fischer 1973). In this study the rate of scale loss was estimated to be $93.5 \%$ in red mullet mortalities of between 7.0 and $13.4 \mathrm{~cm}$ in length (mean length, $11 \mathrm{~cm}$ ). In our winter experiment, the mortality rate of red mullet was inversely related to fish length $(P<0.001)$. However, we observed no clear relation between fish size and scale loss. Scale loss was greater below the lateral line organ than above and scale loss increased towards the tail. The most damaged red mullet scale parts were around the abdomen and caudal peduncle on both flanks (Fig. 8). The fish might have also been hurt by hitting the tail and rubbing the abdomen while passing through.

The majority of authors agree that fish suffer from skin injuries during and after their passage through the trawl meshes (Main and Sangster 1990, Soldal et al. 1993, Breen 2004, Broadhurst et al. 2006, Ingólfsson et al. 2007). In our study, approximately $20 \%$ of the red mullet suffered skin injuries (without tissue or fin loss) that were widely distributed over the fish body. When including tissue loss, more than half of the escapees suffered skin injuries (54.5\%). The upper part of the fish head had the highest deformation percentage, as was also found in the study by Metin et al. (2004). Ingolfsson et al. (2002) found no difference in the rate of the skin injuries of haddock between various cage categories (mesh, grid, and control), which occurred at $\sim 40 \%$. They noted that the number of skin injuries (bleeding and wounds) increased from snout to tail. Conversely, we observed that skin injuries occurred around the head of the fish (particularly on their snouts) and at the abdomen, with minor differences noted between the left and right flanks of mortalities (Fig. 9).

The highest rate of tissue damage was in the flank area (sections 1 and 8 ) in the upper part of the red mullet. Although these areas have the lowest scale density; the skin on the upper part of the head was often injured while passing through trawl meshes. In such cases, the progression from skin damage to tissue damage was responsible for post-capture mortality. It was generally observed that the majority of the injured red mullets continued to swim in a head-up vertical position and therefore continuously hit their heads against the knotless net. Subsequently, some of these fish lost tissue around the head region due to friction and impact between the skin and netting material.

Finally, we investigated the rate and types of fins damage in the red mullet after capture. Torn, broken and lost fins were all identified. Ingólfsson (2006) noted fin splitting, bruises, lesions, and tissue loss for cod, haddock, and saithe. The caudal fin of red mullet was the most frequently injured, followed by the second dorsal fin. For haddock, the dorsal and caudal fins were also the most frequently damaged, whereas ventral fins had the lowest frequency of injury (Ingólfsson 2006). For red mullet, the injury rates of the dorsal and caudal fins were significantly higher than the other fins $(P<0.05)$. While the second dorsal, pectoral and caudal fins were the most likely to suffer from broken fin rays. The first dorsal fins (with 8-9 spines) have been shown to be more resistant to impacts than the second dorsal fine, which consists of one spine and 8 soft rays (Fischer 1973). Likewise, in all fin injury categories damages decreased towards the fish head. The rate of injuries in the first fin group (consisting of the caudal, second dorsal, and anal fin) was approximately $20 \%$ higher than in the second group (consisting of the pectoral and pelvic fins).

In conclusion, the results presented here are consistent with a proportion of the fish that escape through the codend meshes sustaining injuries that might lead to mortality. Multiple factors (including mesh size and shape, water temperature, species types, and fish density) were responsible for the death of fish during and after the escape process. We propose that trawl gears should be modified to reduce total fishing mortality by increasing mesh size, altering mesh shape (e.g., to square mesh codends) and improving soft netting materials (including the sorting grids and escape panels). In the course of the presently reported study we determined the proportion of injured fish among the mortalities, however, future studies should investigate the percentage of fish that survived sustained injuries while escaping. Further research should also address technical and experimental difficulties such as predation effect, species composition and variation in the number of fish within cages. This study focused on investigating the types and occurrence of deformation for red mullet escapees to better understand the cause of their death. The proportions of escape mortalities are vital for fishery management in multi-species fisheries. In addition, the relation between fish escaping from codends and their death should be investigated for more species.

\section{ACKNOWLEDGEMENTS}

The authors would like to thank to our colleagues, $\mathrm{BSc}, \mathrm{MSc}$, and $\mathrm{PhD}$ students and divers from the Faculty of Fisheries, Ege University, for their assistance during the field study, and to the Scientific and Technological Research Council of Turkey (TÜBİTAK) for financial support (Project No: 110-O-335).

\section{REFERENCES}

Anonymous 2004. Report of the study group on unaccounted fishing mortality. ICES CM 2004/B 9, 3p.

Breen M. 2004. Investigating of the mortality of fish escaping from towed fishing gears - a critical analysis. Doctor of Philosophy thesis. University of Aberdeen, Scotland.

Broadhurst M.K., Kenelly S.J., Barker D.T. 1997. Simulated escape of juvenile sand whiting (Sillago ciliata, Cuvier) through square-meshes: Effects on scale-loss and survival. Fisheries Research 32 (1): 51-60.

DOI: 10.1016/S0165-7836(97)00037-4

Broadhurst M.K., Suuronen P., Hulme A. 2006. Estimating collateral mortality from towed fishing gear. Fish and 
Fisheries 7 (3): 180-218.

DOI: $10.1111 / j .1467-2979.2006 .00213 . x$

Davis M.W., Ottmar M.L. 2006. Wounding and reflex impairment may be predictors for mortality in discarded or escaped fish. Fisheries Research 82 (1-3): 1-6.

DOI: 10.1016/j.fishres.2006.09.004

Düzbastılar F.O., Aydın C., Metin G., Lök A., Ulaş A., Özgül A., Gül B., Metin C., Özbilgin H., Şensurat T., Tokaç A. 2010a. Survival of fish after escape from a $40 \mathrm{~mm}$ stretched diamond mesh trawl codend in the Aegean Sea. Scientia Marina 74 (4): 755-761. DOI: $10.3989 /$ scimar.2010.74n 4755

Düzbastılar F.O., Özbilgin H., Aydın C., Metin G., Ulaş A., Lök A., Metin C. 2010b. Mortalities of fish escaping from square and diamond mesh codends in the Aegean Sea. Fisheries Research 106 (3): 386-392. DOI: 10.1016/j.fishres.2010.09.008

Düzbastılar F.O., Özgül A., Aydın İ., Gül B., Soykan O. 2010c. A preliminary study on the survival of brown comber, Serranus hepatus (Actinopterygii, Perciformes, Serranidae), escaping from the codend of a bottom trawl. Acta Ichthyologica et Piscatoria 40 (1): 27-36. DOI: 10.3750/AIP2010.40.1.04

Fischer W. (ed.) 1973. FAO species identification sheets for fishery purposes: Mediterranean and Black Sea (fishing area 37). Vol. 1-2. FAO, Rome.

Gilman E., Suuronen P., Hall M., Kennelly S. 2013. Causes and methods to estimate cryptic sources of fishing mortality. Journal of Fish Biology 83(4): 766-803. DOI: $10.1111 /$ jfb. 12148

He P., Wardle C.S. 1988. Endurance at intermediate swimming speeds of Atlantic mackerel, Scomber scombrus L., herring, Clupea harengus L., and saithe, Pollachius virens L. Journal of Fish Biology 33: 348-360. DOI: $10.1111 /$ j.1095-8649.1988.tb05468.x

Ingólfsson Ó.A. 2006. Size selectivity and escape mortality of gadoid fish in the Barents Sea trawl fishery. PhD thesis. Department of Biology University of Bergen, Norway.

Ingolfsson O.A., Soldal A.V., Huse I. 2002. Mortality and injures of haddock, cod and saithe escaping through codend meshes and sorting grids. ICES CM 2002/V: 32.

Ingólfsson Ó.A., Soldal A.V., Huse I., Breen M. 2007. Escape mortality of cod, saithe, and haddock in a Barents Sea trawl fishery. ICES Journal of Marine Science 64 (9): 1836-1844. DOI: $10.1093 /$ icesjms/fsm150

Main J., Sangster G.I. 1990. An assessment of the scale damage to and survival rates of young gadoid fish escaping from the cod-end of a demersal trawl. Scottish Fisheries Research Report No. 46.

Metin C., Tokaç A., Ulaş A., Düzbastılar F.O., Lök A., Özbilgin H., Metin G., Tosunoğlu Z., Kaykaç H., Aydın C. 2004.
Survival of red mullet (Mullus barbatus L., 1758) after escape from a trawl codend in the Aegean Sea. Fisheries Research 70 (1): 49-53.

DOI: $10.1016 /$ j.fishres.2004.06.013

Olsen R.E., Oppedal F., Tenningen M., Vold A. 2012. Physiological response and mortality caused by scale loss in Atlantic herring. Fisheries Research 129-130, 21-27.

DOI: 10.1016/j.fishres.2012.06.007

R Development Core Team 2007. R: a language and environment for statistical computing. R Foundation for Statistical Computing, Vienna, Austria. http://www.R-project.org

Rottmann R.W., Francis-Floyd R., Durborow R. 1992. The role of stress in fish disease. SRAC Publication No. 474. Southern Regional Aquaculture Center, Stoneville, MS, USA.

Sangster G.I., Lehmann K., Breen M. 1996. Commercial fishing experiments to assess the survival of haddock and whiting after escape from four sizes of diamond mesh cod-ends. Fisheries Research 25 (3-4): 323-345.

DOI: 10.1016/0165-7836(95)00430-0

Soldal A.V., Engås A., Isaksen B. 1993. Survival of gadoids that escape from a demersal trawl. ICES Marine Science Symposia 196: 62-67.

Soldal A.V., Isaksen B., Marteinsson J.E., Engås A. 1991. Scale damage and survival of cod and haddock escaping from a demersal trawl. ICES CM 1991/B:44.

Suuronen P. 2005. Mortality of fish escaping trawl gears, FAO Fisheries Technical Paper No. 478. FAO, Rome.

Suuronen P., Erickson D.L., Orrensalo A. 1996a. Mortality of herring escaping from pelagic trawl codends. Fisheries Research 25 (3-4): 305-321.

DOI: 10.1016/0165-7836(95)00446-7

Suuronen P., Lehtonen E., Jounela P. 2005. Escape mortality of trawl caught Baltic

cod (Gadus morhua) - The effect of water temperature, fish size and codend catch. Fisheries Research 71 (2): 151-163. DOI: 10.1016/j.fishres.2004.08.022

Suuronen P., Perez-Comas J.A., Lehtonen E., Tschernij V. 1996b. Size-related mortality of herring (Clupea harengus L.) escaping through a sorting grid and trawl codend meshes. ICES Journal of Marine Science 53 (4): 691-700. DOI: $10.1006 /$ jmsc. 1996.0088

Wileman D.A., Ferro R.S.T., Fonteyne R., Millar R.B. 1996. Manual of methods of measuring the selectivity of towed fishing gears. ICES Cooperative Research Report No. 215.

Received: 25 September 2014 Accepted: 26 January 2015 Published electronically: 31 March 2015 